\title{
Socio-Cultural and Economic Drivers for Women Participation in Leadership of Nyeri County Cooperatives, Kenya
}

\author{
*Tabitha Wanjiku Njenga \& ${ }^{1}$ Dr. Jane Njoroge \\ *Masters Student, Department of Public Policy and Administration \\ ${ }^{1}$ Lecturer, Department of Public Policy and Administration \\ Kenyatta University, Kenya
}

\begin{abstract}
Social cultural and economic drivers affect women involvement and equal participation in leadership in cooperative movements. Although many countries have been able to develop the appropriate measures, implementations are still the major throwback to the realization of these development agendas. For sustainability, an enabling environment should be created to enable all stakeholders to actively take part in cooperative movement regardless of the various challenges. The study aimed to research on how the social, economic and cultural drivers determine women's ability to participate in the running of and day to day activities of cooperative movement in Kieni East Sub County, in Nyeri County, Kenya. The study used descriptive research design to accomplish its objectives and the target population was 205 women. The study employed purposive sampling and the target members were identified and then a selection of the members done with regard to the study objectives. The study used primary data and secondary data. The data was collected by use of both semi-structured questionnaires and interview guides. Data analysis was conducted objectively. Statistical Package for Social Sciences (SPSS) version 20.0 was utilized to analyse the collected data. Data analysis employed both quantitative and qualitative analysis; quantitative analysis used both descriptive and inferential statistics. Qualitative analysis on the other hand used content analysis. The findings were the presented with the help of tables, frequencies, and percentages. Pilot test of the measures was conducted against prospective sample population to measure validity and reliability. Test re-test method was used to measure the validity of the research instruments. The study concluded that social cultural factors affect women in participating in leadership positions in cooperative movements. It is therefore the mandate of every individual, the government and the non-governmental organizations to look on how to create awareness concerning women in leadership in order to reduce the gap that has been evident in the study. Future studies should try to comparatively compare these results to other sub-county away from Mt. Kenya, or also seek to evaluate how these factors affect women participation in leadership position in other sectors like the private sector of employment.
\end{abstract}

Key words: Women participation in leadership, Participation. Women Involvement, Cooperative Movement, Socio-Cultural Factors

\section{INTRODUCTION}

\subsection{Background of the Study}

Cooperative societies are not new in Kenya but before we put our emphasis in the Kenyan context, we must get a short historical view on cooperative movement. Robert Owen is regarded as the father of modern cooperative movement. He is remembered on how he first came up with a movement aimed at improving workers working conditions. Other pioneers who undertook Owen's ideas of forming an organization are Dr. William King whose ideas have greatly influenced the modern world cooperative movement. Most cooperatives began at around the $19^{\text {th }}$ century in Britain. These however were faced by several challenges in terms of presentation. It was at such a time when women movements had sprung up and were all fighting for representation in all spheres of life ${ }^{[1]}$. Cooperatives movement around the world have in all time strived to offer support to its members. This support may be in terms of finance and social support. It is also good to note that most cooperatives serve a bigger role when it comes to rebuilding the society. However, many cooperative movements tend to have interior challenges when it comes to matters of presentation. These global studies will give us the baseline and help us to study more about women participation in leadership of Nyeri County Cooperatives in Kenya. 
Although the cooperative movement in Kenya are active and vibrant in their activities, they still face some challenges of representation ${ }^{[2]}$. Since this cooperative movement have a form of leadership to enable them to offer their services, it has been noted that most of the Kenya cooperative movement need to be gender sensitive and ensure that women get an opportunity to also participate actively in the leadership of these cooperative movement. The challenges of representation may be pointed to the fact that most societies still disregard women's input in daily activities.

[3] The society has some practices and beliefs which affect member's involvement in leadership positions. These practices and beliefs regarding leadership are gender biased and they therefore exclude women using the patriarchal principle furthermore, traditions and other societal barriers also poses a challenge to women active participation in leadership (Bradley 2011). Also, in most communities, the norm of matriarchy and the fight between male chauvinism has been the highest challenge to women active participation. It is indeed true to say that women are seen as inferior beings in most societies, and they are subjected to just conducting domestic chores at home, while their counterparts continue to make it in other areas in the community ${ }^{[4]}$.

In many cultures especially in Africa, women are subjected to the abusive and unrealistic patriarchal customary laws that aim at guiding the community at the expense of making women inferior. These leads to discrimination when it comes to issues like inheritance and hence a war is always there between men and women whether felt or not. ${ }^{[5]}$. ${ }^{[6]}$ assertion on the control of productive resources still lies in the hands of the men. Women are not able to own land, make decision in areas like Agriculture or so. The land reform especially in Kenya where the constitution allows equal land ownership rights do not get implemented when need arises. It is only about $1.62 \%$ of women who are estimated to have lands registered by their names and it worse since what they own is only a half of what their counterparts own. ${ }^{[7]}$.

\subsection{Statement of the Problem}

The human right Act clearly states that participation in leadership whether by means of direct or indirect participation is crucial to any person and should be practiced. Although this is well known and even agreed by many, women are still left behind or rather finds themselves behind when it comes to leadership participation ${ }^{[8]}$. Active participation of women in the whole process of decision making and running of cooperative movement with equal grounds and terms as their fellow counterparts is an issue that has been evident and need to be looked into to ensure future prosperity and sustainability in development ${ }^{[9]}$ stated that in the twenty-first century, women are facing obstacles in their leadership participation worldwide. Women around the world at every socio-political level find themselves under-represented in cooperative movement. In Nyeri County, most women remain to be members with no opportunity to fully take part in the running of the cooperative movement.

For effective service delivery, women participation in leadership positions in cooperative movement is key. Although their representation over time has not been so effective, women need also to be given an opportunity. To help them struggle less, women need to be given a viable environment free from cultural, social and economic barriers. Lack of women participation can be pointed to the fact that the national sphere puts a picture of not giving women an opportunity. This goes on to the cooperative movement whereby women participation in leadership position becomes an issue. In Kenya, with the new Constitution of Kenya $2010,{ }^{[10]}$, women are granted constitutional rights to take part in any affairs affecting their life. It is laid under article 81 that in any legislature, there is $2 / 3$ gender rule to be upheld. Although this rule is constitutional, women in Kenya continue to face a few challenges that this research aims to address.

\section{Significance of the study}

The world is changing; women and men are trying hard to ensure that various goals are achieved. Women's voices more than ever need to be incorporated in life spheres. As other nations continue to formalize the agenda of women inclusion, we need to ask ourselves when and how we can ensure that we too meet the set goals concerning women in leadership and in this case women participation in cooperative movement. To achieve the millennium goals, we need every individual's input; women, men, boys, and girls. This research aimed to act as part of the means and ways to try and understand the participation in leadership of women in cooperative movement and how social, economic, and cultural drivers influence their participation.

In Kenya, women who are in active leadership roles in the biggest companies are very few. Much of these companies are parastatals which would have been the best arena for women to show their skills in terms of leadership, but they have failed in that men still continue to be the only one in active participation in leadership positions especially in those big roles like managerial. Another research shows that women are now coming out very strongly and taking those roles in spite of the challenges they face. This is evident even in the political arena where we have three women who were elected as governors in the 2017 elections although one has passed away. But it is also shocking that after all these steps; women and girls are still behind and way away from their male counterparts who took away the 44 gubernatorial seats. 
Obstacles like political parties having negative attitude in nominating women or even financing them in their pursuit to look for elective posts continue to be seen and it is with this in mind that this research is undertaken. It is also evident that most women face a number of challenges when it comes to participating in leadership positions. Such challenges stretch from cultural barriers and even to the family context where members fear of losing a domestic worker.

The research will be important to local authorities, Government, policy makers in understanding the obstacles women leaders' encounters despite the international conventions and agreements stressing on the role that women play to ensure there is equal and active participation in leadership and in this case participation in cooperative movement.

The research will be significant to women of Kieni East Sub County in Nyeri County, Gender experts, NGO, CBOs, cooperative movements, Development Partners and Women groups as they will formulate policy to develop strategies to improve women in participation in cooperative movements. The research will also be of great importance in supplementing the research done earlier regarding the same topic but in Nyandarua County. The cooperative movement is the focus due to farmers' interests and where women are the major actors. Most studies done prior to this were done before the Constitution of Kenya, 2010. This means that some information regarding women and leadership may have not been tackled as the Constitution of Kenya, 2010 suggests. This study will aim to ensure that justice is done to the Constitution of Kenya, 2010 and will also seek to bring the ideas and consider how they have affected women participation in leadership of Nyeri County Cooperatives.

\section{Objectives of the Study}

1. To examine how cultural factors affecting women participation in leadership of Nyeri County cooperatives, Kenya.

2. To assess how social factors affecting women participation in leadership of Nyeri County cooperatives, Kenya.

3. To evaluate how economic factors affecting women participation in leadership of Nyeri County cooperatives, Kenya.

\section{LITERATURE REVIEW}

Feminist theory was used to spot the women under representation in various social, political, and economic aspects in the society. It aimed at looking at how women understood their roles and how for a long time they had been marginalized by the patriarchal society. The feminist theory has three pillars; Liberal feminism, Marxist and Socialist feminism, and Development feminism, from the liberal feminism perspective, nothing is of greater good to men which can be of denial to women. Men and women, all face similar challenges and therefore, they should too be ready to get equal opportunity in representation ${ }^{[1]}$. Most feminist around the world have taken the mandate to shade light to all women in every corner through various means. One of the ways is the use of literature where women express their stand, abilities and interests. One such writer is the renown Nigerian author Chimamanda Ngozi whose works like Purple Hibiscus, Half of a Yellow Sun among others have brought to the limelight the challenges that women go through and how best to address them ${ }^{[12]}$. Development feminism on the other hand emphasizes on how all mankind can be subjected to equal rights to act at any given time. The have been at the forefront to fight for equal access to education among men and women, access to economic resources and control over them. They believe that what a man can do in one area, women too can perform well in the same area when given equal opportunity. They agitate for total and sustainable development that does not leave one gender behind. They aim at rebuilding girl's motivation, interest, self- esteem and confidence amid the continued deprivations from their male counterpart.

African feminism theory points out to the woman of Africa. While feminism theory addresses the European woman, African women felt that their needs and contextual experiences were not covered by European women movements. Women, throughout African continent are getting their hands up through every media that is available to ensure that their conditions are addressed and that they input is felt in leadership positions ${ }^{[13]}$. African feminism in Kenya has played indeed a great deal in ensuring that the African woman realizes her full potential specifically in the political field. Women need to be conscious about their rights and what they can do to improve it. While the feminist movements across Europe aimed at making the woman to be equal to men, African feminism aimed at first addressing the specific conditions like culture that kept on reversing women efforts towards engaging in leadership.

It was prudent to note also that it is through African feminism movements that countries like South Sudan have been able to pass and implement gender rule in the legislature. Therefore, Kenya too needed to understand that empowering women is not a way of disempowering men and should therefore be ready for women inclusion in leadership. Women participation is key in leadership. Their domestic roles sometimes make them unreliable in the political arena. African feminism aims to ensure that men and women, girls and boys have equal rights in participating in leadership. For a better participation, studies show that there should be proper plan regarding time, venues and the whole procedure of meetings concerning political issues in order to make sure that both genders participate effectively. 


\subsubsection{Gender and Development theory}

Writings by scholars like Oakley ${ }^{[12]}$ and Rubin ${ }^{[14]}$; have greatly shaped gender and development as a discipline. Although they all in one way or the other ignored the role which women play at every societal level and thus failed to address their issues properly when developing development goals and agendas, it is evident that their input was key in shaping today's development agendas that include women as key stakes. On one side, (WID) the women in development approach aimed at recognising women and how their effective role in participation shaped the society. It aimed at ensuring all women from different classes and women of colour get equal opportunity and are not excluded in the development agenda ${ }^{[15]}$.

Sustainable development to be achieved and the millennium goals to be realized, there is need to for women's roles and responsibilities to be relooked into to offer a better ground for both genders. Research has shown that women inclusion in the day-to-day activities in an active manner should include all members of the community and not necessarily women alone but men too. This is the point behind the development of initiatives like Gender and Development (GAD). The initiative aims at empowering women and at the same time empowering women to avoid crisis. ${ }^{[16]}$.

Gender and Development theory looks at the how division of labor has been done and its effect to women participation in leadership. Who does what and what time? It also focuses on power allocation. The idea behind this is that there are roles which are ascribed to one gender and have made that one gender to lag in terms of participation. Power division is also a key aspect. Who has power over, power within and power to are the most tackled questions in this theory? The theory uses two main frameworks, the gender roles and the social relation theory in determining different aspects.

\subsection{Empirical Literature Review}

Globally, it is evident that women are the most affected by cultural factors which lie in every community. These cultural factors include unfavourable traditions, gender biased stereotypes, social norms, poverty, domestic violence among others. ${ }^{[17]}$ ) on the other hand, gender hierarchy practices in the family, laws that govern aspects of inheritance, customs and values all tend to support men despite their conduct and thus leaving women behind. This get reflected in other social aspects like, places of worship, education, health sectors among others where it remains to be a male dominated game. Women lack a voice to participate fully.

Other studies scholars ${ }^{[18]}$ show that in many countries, women continue to do the highest share of domestic chores. This is seen as the most challenge that hinders them from actively taking part in leadership positions. Their major role is seen really when it comes to family level and providing basic needs like food. Also, to note is the rate at which women get absorbed in the job market. The rate is too low and thus many women remain to be full time stay at home mothers. The few who get opportunities have to balance between domestic chores, work and participating in leadership. ${ }^{[19]}$ The societal beliefs and practices normally exclude women from participating in leadership positions. The society in itself is a masculine being whereby only the men who have been socialized to be so get an opportunity to take part fully. The time frame is always not friendly with women. Most meetings are conducted at a time when the society needs the woman to be at home to attend to her family. Generally, men are the ones accrued with the opportunity to take what they want. In the society, men do business; they are learned people, inventors and scientists. They are the one also to who should enforce law and order. This can be clearly be looked from the point that men were the ones who were required to take care of the members of the family at night by offering security. This was then socialized when communities became rationalized until now that not many things have changed. Culture still finds its way in propagating all these aspects. $^{[20]}$

Cultural influences all in one hand have some aspects in common. They all share some values, practices, stereotypes, norms, beliefs, identities among others. These aspects are learnt and can as well be relearnt, but they are the ones that generally shapes a community and gives it an identity. Gender roles continue to make women lag in matters of leadership. It is evident that in most communities, men take up all responsibilities. Women are left with the role of upbringing children and they are always blamed if a child misbehaves. In other societies, when a kid misbehaves, the kind termed to be the mother's kid but when the kid does well, that is the time it becomes father's kid. See, all these aspects point to the fact that men are superior. During the initiation process, gender also plays a key role in ensuring that boys and girls are socialized differently. While boys are taught aspects of leadership, brevity among others, girls are taught to be good mothers how to maintain the home by cleaning it and remaining indoors. In fact, in a community like Aembu, girls are taught that they should always be present at home when the man is away. Boys also goes to school as opposed to girls who are told to wait for the boys to finish and later marry them. ${ }^{[16]}$. 
Kamau ${ }^{[21]}$ also stresses on how marginalization of women has affected their active participation in leadership. Women have been left behind in social avenues and this significantly affects their representation and their input is denied hence they continue to remain indoors waiting to do whatever men will agree on. ${ }^{[22]}$. Moreover, some traditional practices governing land and livestock ownership, access and control over land, and benefits accruing to land produce tend to favour men compared to women. This to a large extent disadvantages woman in accessing credit especially when collateral is required. In 2019 only $10 \%$ of land titles in Kenya were held by women and 15 to $20 \%$ was owned jointly.

\section{CONCEPTUAL FRAMEWORK}

\begin{tabular}{|c|c|}
\hline $\begin{array}{l}\text { Cultural factors } \\
\text { - Traditions and Beliefs } \\
\text { - Gender stereotypes }\end{array}$ & \\
\hline $\begin{array}{l}\text { Social Factors } \\
\text { - Access to education } \\
\text { - } \quad \text { Religious factors }\end{array}$ & $\begin{array}{l}\text { Social - Cultural and Economic Drivers for } \\
\text { Women participation in leadership in } \\
\text { Cooperative Movement } \\
\qquad \begin{array}{l}\text { Number of women allowed to vote in } \\
\text { leadership positions in cooperative } \\
\text { movements }\end{array} \\
\circ \quad \begin{array}{l}\text { Number of women holding leadership } \\
\text { positions in cooperative }\end{array}\end{array}$ \\
\hline $\begin{array}{l}\text { Economic Factors } \\
\begin{array}{l}\text { - Financial Resources (Agriculture and } \\
\text { business) } \\
\text { - Employment (Private and the Public } \\
\text { Sector) } \\
\text { - Land ownership }\end{array}\end{array}$ & \\
\hline
\end{tabular}

Figure 1 Conceptual Framework

\section{RESEARCH METHODOLOGY}

The study adopted Descriptive Research Design. Descriptive research aims at getting information upon which an analysis will be done to come out with conclusions; its probes the research into details. The site of the study was in Nyeri County, Kieni East Sub County which is situated in the Central Highlands of Kenya. The Kenya National Bureau of Statistics (2019) gave some figures about Kieni East Sub County which include a population of 110,376 people at that time of counting and an area of $448 \mathrm{~km} 2$. Kieni East Sub County was selected since it is a farming community where there are cooperatives for Diary, irrigation and Horticultural farming.

The population for this study consisted 265 who were to be issued with the questionnaires were mainly women in Kieni East Sub county from the five major types of cooperative movements namely, producer cooperative movements, consumer cooperative movements, retail cooperative movements, workers cooperative movements and social cooperative movements

The study adopted regression model. The research techniques were used in the process of analysing data. Major conclusions were to be made from the inferential statistics and the representations it would represent. Inferential statistics could also involve the use of correlation and multiple regressions analysis techniques to determine the extent to which the model explained the changes in the dependent variable. The gathered data was presented by use of tables, graphs, and pie charts. The regression equation $\mathrm{Y}=\beta_{0}+\beta_{1} \mathrm{x}_{1}+\beta_{2} \mathrm{x}_{2}+\beta_{3} \mathrm{x}_{3}+\mathrm{e}$ was used. The data collected was analysed using both inferential and descriptive statistics. Both research techniques were used in the process of analysing data. Major conclusions were to be made from the inferential statistics and the representations it would represent. Inferential statistics could also involve the use of correlation and multiple regressions analysis techniques to determine the extent to which the model explained the changes in the dependent variable. Descriptive statistics was 
used to describe and summarise the data. SPSS was also used and it is known for having the ability to process a large amount of data and information at a given time.

\section{RESEARCH FINDINGS}

A total of 205 questionnaires were administered; however, during the actual study, 3 (1.5\%) women did not return their questionnaires. This gave $202(98.5 \%)$ respondents. ${ }^{[23]}$ Categories of response are described as follows: response rate of over $85 \%$-excellent, $70 \%-85 \%$-very good, $60 \%-70 \%$-acceptable whereas below $50 \%$ not acceptable. This study's response rate was therefore excellent.

\section{Descriptive analysis on Cultural Factors}

The responses were on the level of agreement or disagreement on statements based on culture. The results are given below:

Table 1 Culture

\begin{tabular}{|l|l|l|l|l|l|}
\hline Description & Strongly disagree & Disagree & Undecided & Agree & Strongly agree \\
\hline $\begin{array}{l}\text { Culture allows women to } \\
\text { inherit property }\end{array}$ & $150[74.2 \%]$ & $10[5 \%]$ & $15[7.4 \%]$ & $20[10 \%]$ & $7[7.4 \%]$ \\
\hline $\begin{array}{l}\text { Land tenure system affect } \\
\text { tenure system of women }\end{array}$ & $8[3.9 \%]$ & $17[8.4 \%]$ & $10[5 \%]$ & $7[3.4 \%]$ & $160[79.3 \%]$ \\
\hline $\begin{array}{l}\text { Unequal access to property } \\
\text { hinders women's growth and } \\
\text { wellbeing }\end{array}$ & $4[1.98 \%]$ & $23[11.39 \%]$ & $16[7.93 \%]$ & $14[6.91 \%]$ & $145[71.79 \%]$ \\
\hline $\begin{array}{l}\text { Marital status of women is } \\
\text { critical to owning or accessing } \\
\text { property }\end{array}$ & $10[5 \%]$ & $21[10.4 \%]$ & $16[7.93 \%]$ & $15[7.4 \%]$ & $140[69.4 \%]$ \\
\hline $\begin{array}{l}\text { Most women have access to } \\
\text { land but do not legally own it }\end{array}$ & $102[50.3 \%]$ & $7[3.5 \%]$ & $5[2.5 \%]$ & $20[10 \%]$ & $68[33.7 \%]$ \\
\hline
\end{tabular}

The objective was to access and find how cultural factors affect women's ability to engage in leadership in the five sectors of cooperative movements. The research looked into various aspects of culture and how each aspect affected women participation in leadership of cooperative movements in Kieni Sub County, Nyeri County.

Traditions refers to that which is practised by a certain community and is undertaken to be right and should be followed and passed down from one generation to the other ${ }^{[24]}$. In this research, we realized some of the aspects of traditions and how they affected women in leadership positions. The aspect that was studied in this research are property inheritance, land tenure system, security of women, unequal access to property, marital status and Land ownership rights.

Table 2 Culture and property inheritance.

\begin{tabular}{|l|l|l|l|l|l|l|}
\hline No. & Statement & Strongly disagree & Disagree & Undecided & Agree & Strongly \\
agree.
\end{tabular}

The table above clearly shows that a good percentage of women in Kieni Sub County still believe that the right to property inheritance does not really favour women. 150 women who accounts for $74.2 \%$ strongly disagreed with the point that culture allowed women to inherit property. Only 7 women who accounts for $3.4 \%$ agreed that culture really allowed women to inherit property. During the study, it was also noted out that the 7 women had their reservations because they all said that they came from families where there were no male siblings. Again, this shows how culture affects inheritance rights. Out of the total 202 women who undertook the study, 10 disagreed, which accounts to $5 \%$ and 20 women agreed, accounting to $10 \%$. $7.4 \%$ of the women were undecided on whether culture affects women inheritance rights. 
The above tend to go in line with the study by Oduol that culture and property ownership has really affected women in entry into leadership. This is because, the right to own property increases women's voice when it comes to leadership matters since even most of the positions are competitive especially during campaigns. Two women who were leaders from Ngukurani Farmers' Cooperative Society pointed out that when they were elected, they spent a lot money during the campaign and what helped them is the assets they had inherited from their parents and which they enjoyed the freedom of using them. The study also noticed that most women especially in the producer cooperatives were only used as a bridge by male counterparts. This concurred with ${ }^{[25]}$ findings that women continue to have unexploited potential in the male dominated society. In his research on 'How women can lead and succeed in cooperative,' he found that the main stumbling block to women success in leadership in men who believe that women empowerment is men disempowerment.

Table 3 Land tenure system

\begin{tabular}{|l|l|l|l|l|l|l|}
\hline No. & Statement & Strongly disagree & Disagree & undecided & Agree & Strongly agree \\
\hline 1. & $\begin{array}{l}\text { Land tenure system } \\
\text { affect tenure system } \\
\text { of women }\end{array}$ & $8[3.9 \%]$ & $17[8.4 \%]$ & $10[5 \%]$ & $7[3.4 \%]$ & $160[79.3 \%]$ \\
\hline
\end{tabular}

The table above shows that, out of the 202 women who responded, 8 women representing $3.9 \%$ strongly disagreed with the statement that land tenure system affects women land rights. On the other hand, 160 women representing $79.3 \%$ strongly agreed with the statement on land tenure system. They strongly agreed with it because they believed that the land tenure system did not really promote women's land security rights. Upon further follow ups, it was noted that out of the 8 women who agreed, six were widowed. 10 women representing $5 \%$ were undecided whether the statement was correct or wrong. The ten women were later identified as women who married to men who came from other regions other than Mount Kenya region. This implies that there need to be a gender sensitization process to ensure that other men to realize the importance of allowing the land tenure system to also favour women. 17 women, comprising of $8.4 \%$ did not agree with the statement too. 7 women making $3.4 \%$ agreed with the statement.

During the study, the number of those who strongly agreed took the highest percentage and this was in line with Michuki's studies (2015 on land tenure systems in Nyeri where he points out that land administration was at forefront of making most women to remain behind in getting ownership and control rights.

It became evident that in most of the producer cooperatives, women only delivered produce which they did not have direct control of their production. This affected women's financial muscle and therefore made them to be reluctant to take up leadership positions. Even when land related cases were taken to legal offices where a conflict occurred, the leadership at those offices comprised of men who ended up looking down at the women and give unfavourable judgements. If women lack tenure security, then their participation in leadership posts is as well affected. They lack the voice since they do not control one of the largest factors of production.

Figure 2 Land rights and Leadership.
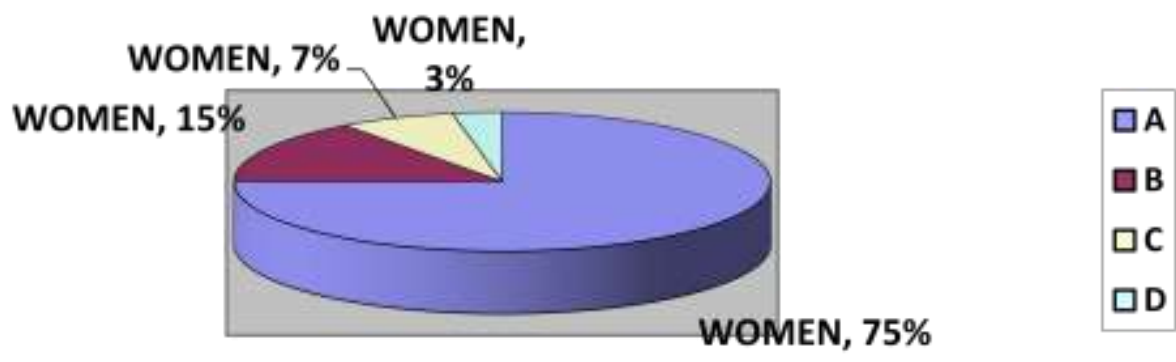

Part A 75\% represent the percentage of women who are not in leadership position and who do not have security over land tenure systems globally. Part B 15\% represents the number of women who are in leadership and have security over land tenure systems. 
Part C 7\% shows number of women not in leadership positions but with land tenure rights globally. Part D 3\% shows the number of women in leadership but without land tenure rights. The above figure seems to go hand in hand with the situation in Kieni Sub County in terms of women in leadership in cooperatives movements.

Table 4 Unequal access to property

\begin{tabular}{|l|l|l|l|l|l|l|}
\hline No & Statement & $\begin{array}{l}\text { Strongly } \\
\text { disagree }\end{array}$ & Disagree & Undecided & Agree & Strongly agree \\
\hline 1. & $\begin{array}{l}\text { Unequal access to property } \\
\text { hinders women's growth and } \\
\text { wellbeing }\end{array}$ & $4[1.98 \%]$ & $23[11.39 \%]$ & $16[7.93 \%]$ & $14[6.91 \%]$ & $145[71.79 \%]$ \\
\hline
\end{tabular}

The above table clearly indicate how the respondent reacted to the statement of whether unequal access to property hinders women's growth and well-being. 4 women accounting to $1.98 \%$ strongly disagreed with the statement making the statement to go in line with the study. [26]. On how women wellbeing and development is mostly hindered from various aspects, his study though based on a global perspective still reflects what this research found out that unequal access to property hinders women's growth keeping in mind that women's growth also has some leadership aspects intertwined within.

Table 5 Regression Coefficients.

\begin{tabular}{|c|c|c|c|c|c|}
\hline \multirow[t]{2}{*}{ Variables } & \multicolumn{2}{|c|}{ Unstandardized Coefficient* } & Standardized & \multirow[t]{2}{*}{$\mathrm{t}$} & \multirow[t]{2}{*}{ Sig. } \\
\hline & B & $\begin{array}{l}\text { Std. } \\
\text { Error }\end{array}$ & Beta & & \\
\hline (Constant) & 0.745 & 0.603 & & 4.622 & .000 \\
\hline Cultural factors & 0.675 & 0.0224 & 1.423 & 2.542 & .002 \\
\hline Economic factors & 0.660 & 0.0224 & 1.418 & 2.554 & .001 \\
\hline
\end{tabular}

Source: Field Data (2021)

As per the SPSS generated table, the equation ( $\left.Y=\beta_{0}+\beta_{1} X_{1}+\beta_{2} X_{2}+\beta_{3} X_{3}+\varepsilon\right)$ becomes:

$\mathrm{Y}=0.745+0.53 \mathrm{X}_{1}+0.675 \mathrm{X}_{2}+0.66 \mathrm{X}_{3+} \varepsilon$

Where $\mathrm{Y}=$ Women participation in Leadership Positions

$\mathrm{X}_{1}=$ Cultural factors

$\mathrm{X}_{2}=$ Economic factors

$\mathrm{X}_{3}=$ Social factors

From the above table, cultural factors also had a positive association of $(\beta=0.675, \mathrm{P}$-value $=0.002)$ on women participation in leadership positions in cooperative movements in Kieni East Sub County. This confirmed the study ${ }^{[27]}$ that found out cultural factors play a great role in disempowering women when it comes to participating in leadership. On the other hand, economic factors had a strong association to women participation in leadership in cooperative movements. We can conclude that indeed women still fights to get economical rights due to the societal structure. The table above shows that economic factors had a significant coefficient of $(\beta=0.660, \mathrm{P}$-value $=0.001)$. Finally, social factors had a significant positive coefficient of 0.53 with $\mathrm{P}$ value of $0.004,(\beta=0.53$, P-value $=0.004)$ which clearly indicate that social factors affect women participation in leadership positions in cooperative movements in Kieni East Sub County.

\section{CONCLUSION}

In conclusion, the study really showed how social cultural factors affect women in participating in leadership positions in cooperative movements. It is therefore the mandate of every individual, the government and the non-governmental organizations to look on how to create awareness concerning women in leadership in order to reduce the gap that has been evident in the study.

\section{RECOMMENDATIONS}


$>$ The government to ensure that women's right to own land legally as underlined in the constitution is put into practice.

$>$ The judiciary to ensure smooth and fast judgements on matters concerning land issues like land grabbing, inheritance, and ownership.

$>$ The Non-Governmental organizations to be on the forefront to fight for women's right and also promote awareness among women concerning their right.

$>$ The government to speed up digitalization of lands to ensure smooth land transfer from one person to another. This will create enough time which is otherwise wasted by women looking for land title deeds. Digitalization will ensure women have enough time to also take part in leadership.

$>$ Judiciary to effectively deal with cases concerning land issues especially those filed by widowed women and the divorced.

$>$ Government to ensure that people are made aware of the constitution of Kenya (2010 rules on land ownership and inheritance rights.

\section{REFERENCES}

1. I.C.A (2020) Empowerment during the Pandemic.

2. Lodiaga (2020) Status and advancement of women professionals in agriculture and environmental institutions and public universities in Kenya. Centre for Women Studies and Gender Analysis, Egerton University, Kenya.

3. Bochari, R (2014) Comparative analysis of effects of employee attitudes and service quality against the customer loyalty and customer satisfaction.

4. Fairle (2010) The Practice of social research, Cengage Learning

5. Madden, M. E. (2015). 2004 division 35 presidential address: Gender and leadership in higher education. Psychology of Women Quarterly.

6. Oto (2016) The Politics of the Widowed and Re-marriage among Luos of Kenya. Journal: Vol.1. No:1 pp161-174.

7. K.L.A (2020) Land ownership rights in the Kenyan context.

8. OECD. (2018a). Women's political participation in Egypt barriers, opportunities and gender

9. Kumar, P. (2018). Participation of women in politics: Worldwide experience. Retrieved.

10. Constitution of Kenya (2010) Constitution of Kenya.

11. Shahabudin, S. H. and Singh, J. K. (2010). Academic leadership strategies and skills for women in higher education in Shahabudin. In Asian women leaders in higher education: management challenges for the new millennium. S. H. and Gill K.S. UNESCO Malaysia and University Kebangsaan, Malaysia. pp. 69-93.

12. Oakley, J., (2016). Gender-based barriers to senior management positions: Understanding the scarcity of female CEOs, Journal of Business Ethics, vol. 27, pp. 321-34.

13. Adichie, C.N. (2017) "We Should All Be Feminists.” The Controversy over Chimamanda Ngozi Adichie and Transwomen.

14. Rubio R.M (2014): The achievement of female suffrage in Europe on Women Citizenship,

15. United Nations. (2019). Goal 5: Achieve gender equality and empower all women and girls. 
16. ILO. (2015a). International labor organization bureau for gender quality, Division for the Advancement International Journal of Constitutional law, volume 12 issue. Https:/doi.org/10.10903/con/mot067Journal of Business Venturing accessed on $20^{\text {th }}$ August 2012 .

17. Tai, A. and Sims, R. L., (2015). The perception of the glass ceiling in high companies. Journal of Leadership and Organization Studies. Fall issue

18. Allen, T. D, Herst, D. E., Bruck, C. S. \& Sutton, M. (2010). Consequences associated with work-to-family conflict: A review and agenda for future research. Journal of Occupational. Health Psychology, 5(2), p. 278-308and E. Mburugu (Eds.), African Perspective on Development: Controversies, Dilemmas and Openings. London, UK: James Currey Ltd.

19. Powell, G. N., \& Butterfield, D. A. (2012). Gender, gender identity, and aspirations to top management. Women in Management Review.

20. Schein, V. E. (2011). A global look at psychological barriers to women's progress in management. Journal of Social Issues sensitivity of select political institutions. Retrieved from http://www.oecd.org/mena/governance/womens-politicalparticipation-in-egypt.pdf

21. Kamau (2010) Women Bring a different perspective into leadership? Un Nzomo M.

22. Bombuwela, P. and Alwis, A.A. (2013), "Effects of glass ceiling on women career

23. Mugenda and Mugenda (2003) Qualitative vs Quantitative search. Simple statistics. https://www.statistics .org/qualitative.quantative.html

24. Graburn, S. (2015) What is Tradition?

25. Owiny, T.J. (2015) Ways in Which Women Can Lead and Succeed in Cooperatives.

26. Bradley, C. (2011). The career experiences of African American women faculty: Implications for counsellor education programs. College Student Journal

27. Odiwuor, O.W. (2018) Constraints to Women Participation in Leadership in the Cooperative sub sector in Laikipia District. 